\title{
Copper, zinc, mercury and arsenic content in Micropogonias furnieri and Mugil platanus of the Montevideo coastal zone, Río de la Plata
}

\author{
Diego Corrales ${ }^{1}$, Alicia Acuña ${ }^{1}$, María Salhi ${ }^{2,3}$, Gustavo Saona ${ }^{4}, E_{\text {Enesto Brugnoli }}^{1, *}$ \\ ${ }^{1}$ Oceanografía y Ecología Marina, Instituto de Ecología y Ciencias Ambientales, Facultad de Ciencias, Universidad de la República. \\ ${ }^{2}$ Laboratorio de Análisis de Productos Pesqueros, Dpto. de Industria Pesquera, Dirección Nacional de Recursos Acuáticos, Ministerio de \\ Ganadería Agricultura y Pesca (MGAP), Uruguay. \\ ${ }^{3}$ Laboratorio de Recursos Naturales, Instituto de Ecología y Ciencias Ambientales, Facultad de Ciencias, Universidad de la República, \\ Uruguay. \\ ${ }^{4}$ Servicio de Evaluación de la Calidad y Control Ambiental, Intendencia de Montevideo, Uruguay \\ *Corresponding author: ebo@fcien.edu.uy
}

\begin{abstract}
Metals $(\mathrm{Cu}, \mathrm{Zn}, \mathrm{Hg})$ and metalloid (As) concentrations were measured in Micropogonias furnieri and Mugil platanus caught in three areas along the Montevideo coastal zone during winter 2010, spring 2010 and 2011. Compared to previous studies conducted in the zone, both species showed higher (for $\mathrm{Cu}$ ), similar (for $\mathrm{Zn}$ ) or lower (for $\mathrm{Hg}$ ) concentrations. The highest $\mathrm{Hg}$ values were found in the M. furnieri of Montevideo bay. There was no spatial variation in $\mathrm{Cu}, \mathrm{Zn}$, and As concentrations in muscle, likely due to the high mobility of both species. However, the $\mathrm{Cu}$ content in the liver of $\mathrm{M}$. furnieri was higher in fish from the West zone. $\mathrm{Cu}, \mathrm{Zn}$ and $\mathrm{As}$ found in the liver of M. platanus were much higher than in that of M. furnieri. A functional relationship between muscle levels of $\mathrm{Zn}$ and $\mathrm{Hg}$ and fish length of $M$. furnieri indicates bioaccumulation of these metals. According to the results, M. furnieri may be used as a temporal bioindicator for $\mathrm{Hg}$, but not as a spatial bioindicator. Mercury levels were below the maximum safety level based on international standard values for human consumption.
\end{abstract}

Descriptors: Metals, Fish, Bioaccumulation, Estuary, Human consumption, Río de la Plata.

\section{RESUmo}

Foram estudadas as concentrações de metais $(\mathrm{Cu}, \mathrm{Zn}$, $\mathrm{Hg}$ ) e metaloides (As) em exemplares de Micropogonias furnieri e Mugil platanus coletados em três locais ao longo da costa de Montevidéu (Uruguai) durante o inverno de 2010 e as primaveras de 2010 e 2011 . Comparados com estudos prévios realizados nessas áreas, ambas as espécies apresentaram concentrações maiores (para $\mathrm{Cu}$ ), similares (para $\mathrm{Zn}$ ) ou menores (para $\mathrm{Hg}$ ). Os valores mais elevados de $\mathrm{Hg}$ foram encontrados em $M$. furnieri da baía de Montevidéu. Não houve variação espacial na concentração dos elementos $\mathrm{Cu}, \mathrm{Zn}$, and As, provavelmente devido à alta mobilidade de ambas as espécies. No entanto, a concentração de Cu no fígado de $M$. furnieri foi maior nos peixes da área Oeste. $\mathrm{Cu}, \mathrm{Zn}$ e As foram encontrados em $M$. platanus em valores mais elevados do que no figado de $M$. furnieri. A relação funcional entre os níveis de Zn e Hg no músculo e o comprimento dos peixes em $M$. furnieri indica bioacumulação para estes metais. De acordo com os resultados, M. furnieri pode ser utilizado como bioindicador temporal para $\mathrm{Hg}$, mas não como bioindicador espacial. Os níveis de $\mathrm{Hg}$ registrados estiveram abaixo do nível máximo de segurança com base nos valores do padrão internacional para o consumo humano.

Descritores: Metais, Peixes, Bioacumulação, Estuário, Consumo humano, Río de la Plata. 


\section{INTRODUCTION}

Metals and metalloids are present in aquatic environments and originate from both natural and anthropogenic sources. Low concentrations of essential elements such as zinc $(\mathrm{Zn})$ and copper $(\mathrm{Cu})$ play an important metabolic role in aquatic organisms, while the non-essential mercury $(\mathrm{Hg})$ and arsenic (As) can be toxic at low concentration (LUOMA; RAINBOW, 2011; WANG et al., 2010).

Metals and metalloids may bioaccumulate and biomagnify in aquatic organisms (TAGLIAMONTE et al., 2008; REJOMON et al., 2010). In fish, these elements tend to accumulate in muscle, liver and gills; thus these tissues are the most commonly used to measure contaminant levels (REJOMON et al., 2010). However, bioaccumulation varies with environmental parameters and is also species dependent, (e.g. life history, age, length and sex) (LOMBARDI et al., 2010; REJOMON et al., 2010; WANG et al., 2010; QADIR; MALIK, 2011; ABDOLAHPUR et al., 2013).

Bioaccumulation and biomagnification are a major concern in commercially exploited fish species (BURGER; GOCHFELD, 2005). Micropogonias furnieri (whitemouth croaker) and Mugil platanus (mullet) are among the most abundant fish species in the coastal zone of Montevideo, bordering the Río de la Plata (NIÓN, 1997). The whitemouth croaker is of high economic value since it is the principal resource of coastal fisheries in Uruguay and Argentina, where in the Montevideo coastal zone an important artisanal fishery is undertaken (DEFEO et al., 2009). In this coastal area, the highest pollution load is in Montevideo Bay, notably in the inner bay, due to urban and industrial discharges, industrial activities, and maritime traffic associated with the harbor. However, the west and east of this area are only moderately polluted (MUNIZ et al., 2004; 2011; BRUGNOLI et al., 2007).

Studies of metal contamination in fish from the Montevideo coast are scarce. VIANA et al. (2005) have found evidence of bioaccumulation of $\mathrm{Hg}$ and $\mathrm{Zn}$ in the whitemouth croaker. Both M. furnieri and species of the genus Mugil are considered potential bioindicator species for metal contamination (VIANA et al., 2005; MARCOVECCHIO, 2004; FRANCO; LEÓN, 2012).

The present study was conducted to update and extend the observational records of $\mathrm{Cu}, \mathrm{Zn}, \mathrm{Hg}$, and $\mathrm{As}$ in muscle and liver of $M$. furnieri and M. platanus along the Montevideo coastal zone. It also assesses their quality for human consumption. The potential use of these fish species as bioindicators of metal contamination in the area is also considered.

\section{MATERIAL AND METHODS}

\section{STUDY AREA AND SAMPLING PROCEDURE}

The Montevideo coastal zone has an extension of approximately $50 \mathrm{~km}$. Its major feature is the Montevideo bay, where the principal Uruguayan harbor is located. A total of 75 specimens of Micropogonias furnieri (61) and Mugil platanus (14) were obtained in winter 2010, spring 2010 and spring 2011 from the artisanal fishery at the landing sites of Santiago Vázquez town (West zone), Montevideo Bay (MB) and Punta Carretas, Buceo and Punta Gorda (East zone) (Figure 1).

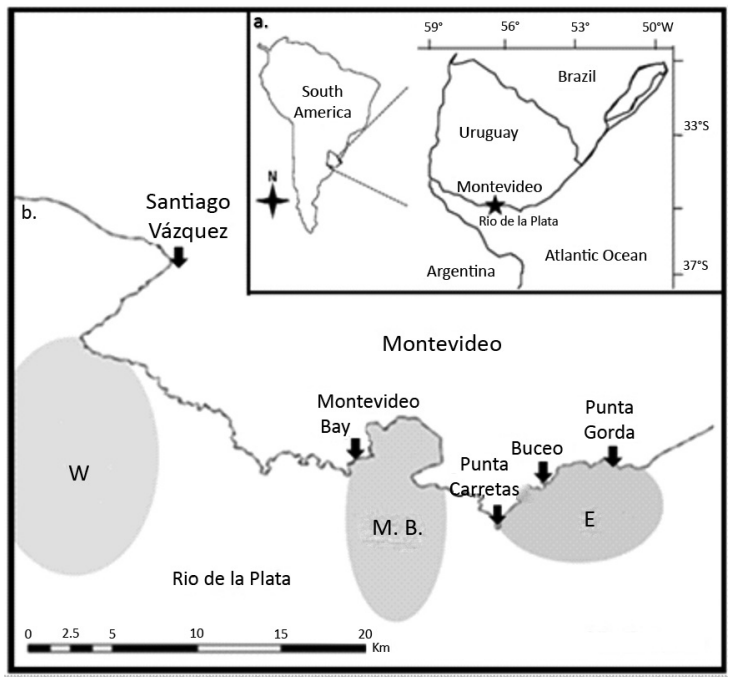

Figure 1. a) Geographical location of Uruguay and Montevideo city b) Capture site along Montevideo coastal zone. W: West zone, M.B.: Montevideo Bay, E: East zone.

The specimens were kept refrigerated at $4^{\circ} \mathrm{C}$ in a cooler and transported to the laboratory for dissection and analysis. Total length $(\mathrm{cm})$ and weight $(\mathrm{kg})$ of each individual were recorded. Based on the protocol of SERICANO and BESADA (2009), two samples from axial muscle and the liver of each specimen were extracted and frozen for further analysis.

\section{ANALYTICAL TECHNIQUES}

$\mathrm{Cu}, \mathrm{Zn}$ and $\mathrm{As}$ were quantified in muscle and liver using Energy Dispersive X-Ray Fluorescence (EDXRF) in the Tecnogestión laboratory (MIEM). The quality assurance system (ISO/IEC 17025) was used throughout the process. The analytical procedure was checked using standard reference materials (Table 1; IAEA-392; IAEA - 336 and NIST 2976). Muscle samples were analyzed individually but pools of 4-5 livers (3-4g) were prepared to meet analytical requirements. 
Table 1. Comparison between experimental results and certified values (mg Kg-1 dry weight) of mussel tissue NIST 2976

\begin{tabular}{lcc}
\hline Element & Certified value & Measured value \\
\hline Copper & $4.02 \pm 0.33$ & $4.4 \pm 0.4$ \\
Zinc & $137 \pm 13$ & $156 \pm 15.0$ \\
Arsenic & $13.3 \pm 1.8$ & $13.3 \pm 2.0$ \\
\hline
\end{tabular}

Total $\mathrm{Hg}$ was quantified only in the muscle tissue by Cold Vapor Atomic Absorption Spectroscopy (CVAAS) in the Laboratory of Analysis of Fishery Products (DINARA, MGAP). Each CVAAS sample of muscle tissue was frozen and grounded until a homogeneous product was obtained and analyzed for $\mathrm{Hg}$ content following $\mathrm{HATCH}$; OTT (1968; modified according to MENDEZ et al., 2001), after validation and accreditation ISO/IEC 17025.

\section{DATA ANALYSIS}

Prior to performing the statistical analyses, values of element concentrations lower than the limit of detection (LOD $\mu \mathrm{g} \mathrm{g}^{-1}$ wet weight (W.W.): $\mathrm{Cu}$ : 0.40; Zn: 0.40; As: 0.80; Hg: 0.04) were replaced by half this value (LOD/2). The element concentrations were expressed as $\mathrm{mg}^{-1}$ W.W.

The average, standard deviation and range of concentrations of elements and fish length of $M$. furnieri and $M$. platanus were calculated for each zone (West zone, MB, and East zone) and seasons (winter 2010, spring 2010, and spring 2011). A functional relationship between the concentration of each metal and $M$. furnieri length was calculated by fitting linear and exponential regressions. The best regression model was selected by choosing the highest coefficient of determination $\left(\mathrm{r}^{2}\right)$. The Analysis of Covariance (ANCOVA) was used to compare the metal concentrations in $M$. furnieri muscle between sampling zone and periods, adjusting for the effect of fish size. The assumptions of normality and homoscedasticity were tested using the Shapiro-Wilk and Levene tests, respectively. The metal concentrations were transformed using the natural logarithm ( $\mathrm{Ln})$ to reduce the heteroscedasticity effect in statistical analyses. P-values lower than or equal to 0.05 were considered significant (ZAR, 1996).

\section{RESULTS}

Detectable levels of $\mathrm{Cu}, \mathrm{Zn}$ and $\mathrm{As}$ were found in muscle and liver tissues of both species. Values of these elements were always much higher in liver than in muscle, sometimes by up to one order of magnitude. Mercury was detected only in $M$. furnieri muscle. However, $\mathrm{Hg}$ was not detectable in a high number of samples $(n=21)$, resulting in high standard deviation of average results (Table 2 and 3 ).

Average $\mathrm{Cu}, \mathrm{Zn}$ and As concentrations in muscle of $M$. furnieri and $M$. platanus were similar along the coast and during all seasons (Tables 2 and 3). On the other hand, values of $\mathrm{Hg}$ found in muscle of $M$. furnieri showed the highest values in Montevideo Bay $\left(0.14 \pm 0.13 \mathrm{mg} \mathrm{g}^{-1}\right.$ W.W.) (Table 2) and were lower in spring 2010 than in winter 2010 and spring 2011 (Table 3).

With regard to the metal content in liver of $M$. furnieri, the average concentrations of $\mathrm{Cu}$ and As were similar across seasons, but $\mathrm{Zn}$ contents incresed from the lowest value in spring $2010\left(33.75 \pm 4.54 \mathrm{mg} \mathrm{g}^{-1} \mathrm{~W}\right.$.W. $)$ to the highest value in spring 2011 (44.48 $\pm 7.93 \mathrm{mg} \mathrm{g}^{-1}$ W.W.). Average $\mathrm{Cu}$ content in liver of $M$. furnieri from the West zone was higher than in the other zones (Table 2). For $M$. platanus, levels of $\mathrm{Cu}, \mathrm{Zn}$ and $\mathrm{As}$ found in the East zone were much higher than those in liver of $M$. furnieri from the same zone (Table 2); levels of As and $\mathrm{Zn}$ in liver of $M$. platanus were higher in winter $2010\left(14.81 \pm 4.58 \mathrm{mg} \mathrm{g}^{-1}\right.$ W.W. and $103.25 \pm 18.44 \mathrm{mg} \mathrm{g}^{-1}$ W.W. respectively) than in spring 2011 (Table 3).

The regression analysis showed that for M. furnieri, $\mathrm{Zn}$ and $\mathrm{Hg}$ contents in muscle were significantly associated with total fish length ( $p<0.05$; Figure $2 \mathrm{a}, \mathrm{b})$. The functional relationships were fitted with linear (for $\mathrm{Zn}$ ) and exponential (for $\mathrm{Hg}$ ) regressions (Figure $2 \mathrm{a}, \mathrm{b}$ ). The ANCOVA showed that $\mathrm{Cu}$ content in muscle of $M$. furnieri was correlated with the season $(p=0.015)$ with significant differences between spring 2010 and spring 2011. Zinc concentrations also varied by season ( $p=$ $0.035)$ and fish length $(p=0.0001)$, although significant differences were observed only between winter 2010 and spring 2011. Arsenic contents showed no significant differences. Mercury content was significantly correlated with season and fish length $(p=0.0006)$, as well as with capture site $(p=0.0004)$ (Table 2 and 3$)$.

In all samples, average muscle concentrations of $\mathrm{Hg}$ (M. furnieri) were below the maximum permitted levels for human consumption $\left(0.5 \mathrm{mg} \mathrm{kg}^{-1}\right.$ W.W.; CODEXSTAN 193-1995, 2010; MERCOSUR, 2011).

\section{DISCUSSION}

Concentrations of metal and metalloid compounds measured in this study were either higher $(\mathrm{Cu}$ in muscle 
Table 2. $\mathrm{Cu}, \mathrm{Zn}$ and $\mathrm{As}$ concentrations in muscle and liver, $\mathrm{Hg}$ concentrations in muscle of Micropogonias furnieri and Mugil platanus samples from West and East zone and Montevideo Bay.

\begin{tabular}{|c|c|c|c|c|c|c|c|}
\hline \multirow{2}{*}{ 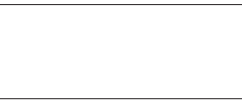 } & \multicolumn{2}{|l|}{$\mathrm{Cu}$} & \multicolumn{2}{|l|}{$\mathrm{Zn}$} & \multicolumn{2}{|l|}{ As } & \multirow[b]{2}{*}{ Muscle } \\
\hline & Muscle & Liver & Muscle & Liver & Muscle & Liver & \\
\hline \multicolumn{8}{|l|}{ West Zone } \\
\hline \multicolumn{8}{|c|}{ Micropogonias furnieri } \\
\hline Length $(47.5 \pm 4.3)$ & & & & & & & $(47.5 \pm 4.3)$ \\
\hline $\mathrm{N}$ & $12(67 \%)$ & $4(100 \%)$ & $12(100 \%)$ & $4(100 \%)$ & $12(92 \%)$ & $4(100 \%)$ & $12(25 \%)$ \\
\hline $\begin{array}{l}\text { Concentration } \\
(\text { Mean } \pm \text { SD })\end{array}$ & $0.40 \pm 0.17$ & $26.50 \pm 7.54$ & $3.56 \pm 0.84$ & $40.79 \pm 6.01$ & $1.82 \pm 1.16$ & $2.55 \pm 0.22$ & $0.05 \pm 0.04$ \\
\hline Range & $<0.40-0.65$ & $21.00-37.62$ & $2.58-5.27$ & $36.96-49.65$ & $<0.80-4.09$ & $2.24-2.76$ & $<0.04-0.14$ \\
\hline \multicolumn{8}{|l|}{ Montevideo Bay } \\
\hline \multicolumn{8}{|c|}{ Micropogonias furnieri } \\
\hline $\begin{array}{l}\text { Length } \\
(46.6 \pm 10.8)\end{array}$ & & & & & & & $(47.2 \pm 11.2)$ \\
\hline $\mathrm{N}$ & $22(64 \%)$ & $6(100 \%)$ & $22(100 \%)$ & $6(100 \%)$ & $22(68 \%)$ & $6(100 \%)$ & $19(53 \%)$ \\
\hline $\begin{array}{l}\text { Concentration } \\
(\text { Mean } \pm \text { SD })\end{array}$ & $0.36 \pm 0.15$ & $16.30 \pm 6.09$ & $3.62 \pm 0.72$ & $43.17 \pm 9.26$ & $1.26 \pm 0.81$ & $1.88 \pm 0.50$ & $0.14 \pm 0.13$ \\
\hline Range & $<0.40-0.62$ & $10.44-27.59$ & $1.93-4.94$ & $28.76-53.79$ & $<0.80-3.08$ & $0.95-2.32$ & $<0.04-0.48$ \\
\hline \multicolumn{8}{|l|}{ Mugil platanus } \\
\hline \multicolumn{8}{|l|}{ Length (44.0) } \\
\hline $\mathrm{N}$ & $1(100)$ & $1(100)$ & $1(100)$ & $1(100)$ & $1(100)$ & $1(100)$ & $1(0)$ \\
\hline Mean value & 0.6 & 487.6 & 3.2 & 96.2 & 1.26 & 19.77 & $<0.02$ \\
\hline Range & - & - & - & - & - & - & - \\
\hline \multicolumn{8}{|l|}{ East Zone } \\
\hline \multicolumn{8}{|c|}{ Micropogonias furnieri } \\
\hline Length $(47.2 \pm 8.9)$ & & & & & & & $(46.8 \pm 9.1)$ \\
\hline $\mathrm{N}$ & $27(63 \%)$ & $12(100 \%)$ & $27(100 \%)$ & $12(100 \%)$ & $27(67 \%)$ & $12(100 \%)$ & $25(32 \%)$ \\
\hline $\begin{array}{l}\text { Concentration } \\
(\text { Mean } \pm \mathrm{SD})\end{array}$ & $0.40 \pm 0.18$ & $19.17 \pm 9.03$ & $3.67 \pm 0.35$ & $42.61 \pm 8.86$ & $1.45 \pm 1.24$ & $2.71 \pm 0.79$ & $0.06 \pm 0.05$ \\
\hline Range & $<0.40-0.80$ & $6.30-43.21$ & $2.90-4.26$ & $30.51-53.97$ & $<0.80-5.43$ & $1.61-4.05$ & $<0.04-0.19$ \\
\hline \multicolumn{8}{|l|}{ Mugil platanus } \\
\hline \multicolumn{8}{|l|}{ Length $(45.6 \pm 10.2)$} \\
\hline $\mathrm{N}$ & $13(77 \%)$ & $6(100 \%)$ & $13(100 \%)$ & $6(100 \%)$ & $13(69 \%)$ & $6(100 \%)$ & $13(0 \%)$ \\
\hline $\begin{array}{l}\text { Concentration } \\
(\text { Mean } \pm \mathrm{SD})\end{array}$ & $0.63 \pm 0.33$ & $\begin{array}{c}486.72 \pm \\
272.69\end{array}$ & $4.81 \pm 0.63$ & $93.96 \pm 35.59$ & $1.13 \pm 0.56$ & $8.01 \pm 4.46$ & $<0.04$ \\
\hline Range & $<0.40-1.90$ & $20.36-773.75$ & $4.05-5.76$ & $60.96-142.89$ & $<0.80-1.94$ & $3.76-13.93$ & - \\
\hline
\end{tabular}

Notes: Mean concentrations in $\mathrm{g} \mathrm{g}^{-1} \mathrm{~W} . \mathrm{W}$.; mean value of total length in $\mathrm{cm} . \mathrm{N}$ : total number of individuals analyzed; the percentages (\%) of specimens with concentrations greater than the limit of detection (LOD) are presented in brackets. LOD: Cu: 0.40; Zn: 0.40; As: 0.80; Hg: 0.04 .

and liver from both species), similar ( $\mathrm{Zn}$ in muscle from both species) or lower ( $\mathrm{Hg}$ in muscle from both species) than those reported by VIANA et al. (2005) (Table 4). This study is the first record of As content in muscle tissues of these species for the area and also represents a temporal update in the data for the Montevideo coastal zone. The results obtained in this study showed similar concentrations to those given by the other studies from the region, being within the range of values reported (Table 4). However, it is very important to highlight that the samples used in these studies are not standardized. They adopted different sampling methods and periods, with variations in the number of samples and sizes of the fish analysed. Because of these differences, it is important to be cautious when comparing different studies and drawing conclusions. 
Table 3. $\mathrm{Cu}, \mathrm{Zn}$ and As concentrations in muscle and liver, and $\mathrm{Hg}$ concentrations in muscle of Micropogonias furnieri and Mugil platanus samples in winter, spring 2010 and spring 2011.

\begin{tabular}{|c|c|c|c|c|c|c|c|}
\hline \multirow{2}{*}{ 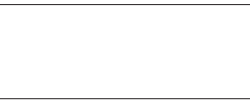 } & \multicolumn{2}{|l|}{$\mathrm{Cu}$} & \multicolumn{2}{|l|}{$\mathrm{Zn}$} & \multicolumn{2}{|l|}{ As } & \multirow{2}{*}{$\begin{array}{c}\mathrm{Hg} \\
\text { Muscle }\end{array}$} \\
\hline & Muscle & Liver & Muscle & Liver & Muscle & Liver & \\
\hline \multicolumn{8}{|l|}{ Winter 2010} \\
\hline \multicolumn{8}{|l|}{ Micropogonias furnieri } \\
\hline Length $(46.0 \pm 5.8)$ & & & & & & & $(46.3 \pm 5.5)$ \\
\hline $\mathrm{N}$ & $18(72 \%)$ & $4(100 \%)$ & $18(100 \%)$ & $4(100 \%)$ & $18(61 \%)$ & $4(100 \%)$ & $14(36 \%)$ \\
\hline $\begin{array}{l}\text { Concentration } \\
(\text { Mean } \pm \text { SD })\end{array}$ & $0.40 \pm 0.18$ & $16.97 \pm 3.56$ & $3.38 \pm 0.48$ & $38.56 \pm 7.57$ & $1.34 \pm 1.25$ & $2.32 \pm 1.32$ & $0.10 \pm 0.13$ \\
\hline Range & $<0.40-0.83$ & $13.57-21.00$ & $1.93-3.86$ & $28.80-47.20$ & $<0.80-4.09$ & $0.95-4.05$ & $<0.04-0.39$ \\
\hline \multicolumn{8}{|l|}{ Mugil platanus } \\
\hline \multicolumn{8}{|l|}{ Length $(50.5 \pm 3.5)$} \\
\hline $\mathrm{N}$ & $6(100 \%)$ & $3(100 \%)$ & $6(100 \%)$ & $3(100 \%)$ & $6(100 \%)$ & $3(100 \%)$ & $6(0 \%)$ \\
\hline $\begin{array}{l}\text { Concentration } \\
(\text { Mean } \pm \mathrm{SD})\end{array}$ & $0.72 \pm 0.09$ & $458.03 \pm 114.66$ & $4.47 \pm 0.87$ & $103.25 \pm 18.44$ & $1.45 \pm 0.24$ & $\begin{array}{c}14.81 \pm \\
4.58\end{array}$ & $<0.04$ \\
\hline Range & $0.60-0.86$ & $331.47-555.00$ & $3.20-5.76$ & $89.36-124.17$ & $1.18-1.80$ & $10.74-19.77$ & - \\
\hline \multicolumn{8}{|l|}{ Spring 2010} \\
\hline \multicolumn{8}{|l|}{ Micropogonias furnieri } \\
\hline Length $(42.3 \pm 6.4)$ & & & & & & & $(41.7 \pm 6.2)$ \\
\hline $\mathrm{N}$ & $18(89 \%)$ & $2(100 \%)$ & $18(100 \%)$ & $2(100 \%)$ & $18(94 \%)$ & $2(100 \%)$ & $17(7 \%)$ \\
\hline $\begin{array}{l}\text { Concentration } \\
(\text { Mean } \pm \mathrm{SD})\end{array}$ & $0.47 \pm 0.12$ & $23.40 \pm 1.33$ & $3.41 \pm 0.66$ & $33.75 \pm 4.54$ & $1.92 \pm 1.17$ & $2.52 \pm 0.34$ & $0.04 \pm 0.01$ \\
\hline Range & $<0.40-0.58$ & $22.46-24.34$ & $2.58-5.27$ & $30.54-36.96$ & $<0.80-5.43$ & $2.28-2.76$ & $<0.04-0.08$ \\
\hline \multicolumn{8}{|l|}{ Spring 2011} \\
\hline \multicolumn{8}{|l|}{ Micropogonias furnieri } \\
\hline \multicolumn{8}{|l|}{ Length $(51.2 \pm 10.3)$} \\
\hline $\mathrm{N}$ & $25(40 \%)$ & $16(100 \%)$ & $25(100 \%)$ & $16(100 \%)$ & $25(72 \%)$ & $16(100 \%)$ & $25(60 \%)$ \\
\hline $\begin{array}{l}\text { Concentration } \\
(\text { Mean } \pm \mathrm{SD})\end{array}$ & $0.32 \pm 0.16$ & $19.95 \pm 9.70$ & $3.96 \pm 0.50$ & $44.48 \pm 7.93$ & $1.20 \pm 0.80$ & $2.48 \pm 0.61$ & $0.11 \pm 0.10$ \\
\hline Range & $<0.40-0.65$ & $6.30-43.21$ & $2.90-4.94$ & $30.51-53.97$ & $<0.80-3.82$ & $1.61-4.00$ & $<0.04-0.48$ \\
\hline \multicolumn{8}{|l|}{ Mugil platanus } \\
\hline \multicolumn{8}{|l|}{ Length $(41.7 \pm 11.5)$} \\
\hline $\mathrm{N}$ & $8(63 \%)$ & $4(100 \%)$ & $8(100 \%)$ & $4(100 \%)$ & $8(50 \%)$ & $4(100 \%)$ & $8(0 \%)$ \\
\hline $\begin{array}{l}\text { Concentration } \\
(\text { Mean } \pm \mathrm{SD})\end{array}$ & $0.55 \pm 0.41$ & $508.46 \pm 337.22$ & $4.82 \pm 0.64$ & $87.55 \pm 37.47$ & $0.99 \pm 0.60$ & $5.84 \pm 3.58$ & $<0.04$ \\
\hline Range & $<0.40-1.29$ & $20.36-773.75$ & $4.05-5.61$ & $60.96-142.88$ & $<0.80-1.94$ & $3.76-11.19$ & - \\
\hline
\end{tabular}

As expected, all elements showed higher concentrations in liver tissues than in muscle, due to the metabolic role of the liver as a major storage site, as well as in regulating and detoxifying (MACEDA-VEIGA et al., 2012; ABDOLAHPUR et al., 2013).

The absence of spatial variability of $\mathrm{Cu}, \mathrm{Zn}$ and As, notably in muscle tissues, may be attributed to the mobility of both species (JAUREGUIZAR et al., 2008). The highest levels of As in liver of M. platanus and $\mathrm{Hg}$ in muscle of M. furnieri, however, were measured in specimens from
Montevideo Bay, which is the most contaminated site in the study zone (DANULAT et al., 2002; MUNIZ et al., 2011). Despite these findings, caution must still be exercised, given that the As in liver of M. platanus was only found in one specimen. More studies on environmental pollution and bioavailability of contaminants must be carried out before causal relationships can be determined.

The amount of contaminants in fish tissue will depend on the element levels in the environment, species' life history, trophic level, metabolism, contaminant type, 

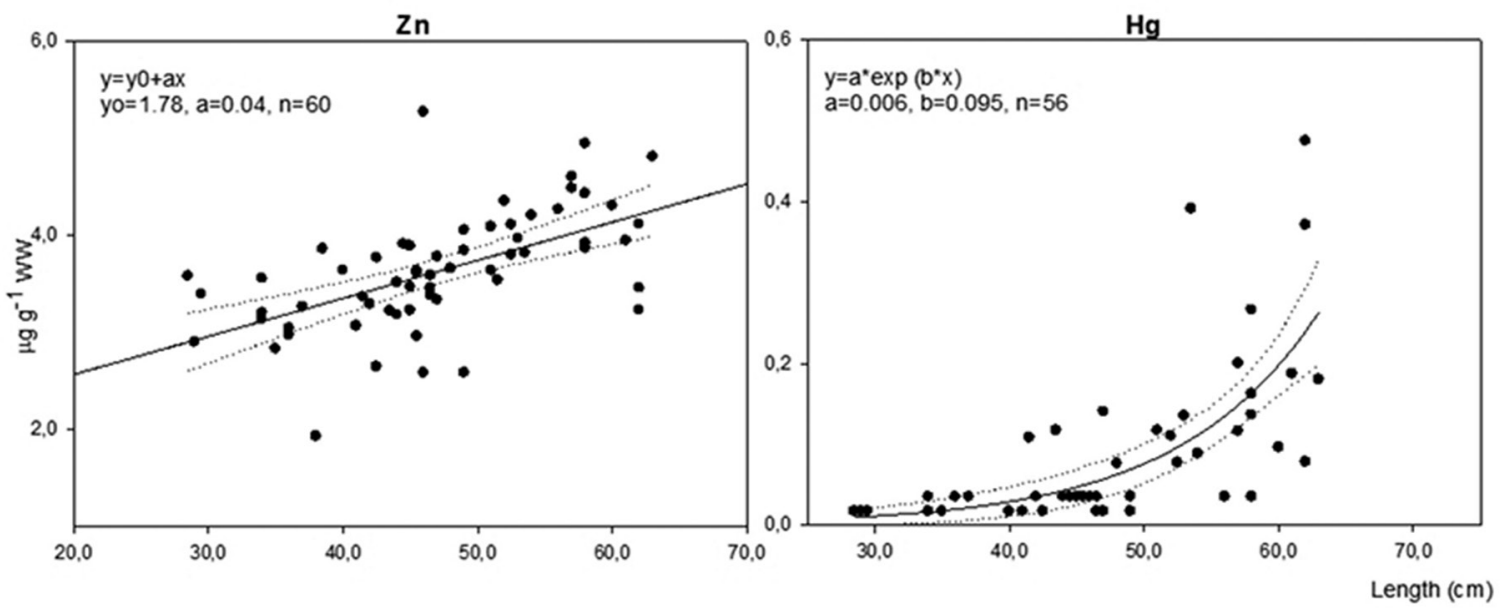

Figure 2. Functional relationship between zinc (a) and mercury (b) concentrations ( $\mu \mathrm{g} \mathrm{g}^{-1} \mathrm{~W} . \mathrm{W}$.) in muscle and total length (cm) of Micropogonias furnieri.

and exposure time (QADIR; MALIK, 2011; MACEDAVEIGA et al., 2012). M. furnieri is a demersal fish, a generalist-opportunist carnivore that reproduces and grows in the estuary (MENDOZA-CARRANZA; VIERA, 2008). M. platanus is a bentho-pelagic species; an iliophagus that spends part of its life in estuarine environments and then migrates to the ocean during the spawning season (FISCHER et al., 2011). Because $\mathrm{Cu}$, $\mathrm{Zn}$, As and $\mathrm{Hg}$ tend to accumulate in sediments (CHENG et al., 2013) both $M$. furnieri and M. platanus will be exposed by virtue of their benthic habitat and feeding habits, and may be prone to biomagnification and bioaccumulation processes.

In this study, M. furnieri showed the highest levels of $\mathrm{Hg}$ and $\mathrm{As}$ in muscle tissue, and a significant functional relationship between $\mathrm{Zn}$ and $\mathrm{Hg}$ concentrations and total length were found. Because of the feeding behavior of whitemouth croaker, these results suggest some degree of biomagnification for these elements, a phenomenon already observed with $\mathrm{Hg}$ in a previous study in the area (VIANA et al., 2005) and in other aquatic ecosystems (KEHRIG et al., 2007). Mercury biomagnification and bioaccumulation in fish depend mostly on the fish's position in the food web and its feeding habits (DSIKOWITZKY et al., 2013). However, As showed contradictory results in the literature in terms of the biomagnification process (DSIKOWITZKY et al., 2013). Finally, the functional relationship found with $\mathrm{Zn}$ and $\mathrm{Hg}$ indicates bioaccumulation in $M$. furnieri for these elements. This relationship, however, was not observed with $\mathrm{Cu}$. The highest levels of $\mathrm{Cu}$ were found in spring 2010 when the fish were the smallest in size. This bioaccumulation behaviour could be due to different reproductive status, since $M$. furnieri breeds in spring (JAUREGUIZAR et al., 2008) and the specimens studied were of mixed immature and mature stages. The reproductive status can affect the concentration of metals in the liver (MONSEFRAD et al., 2012). Although VIANA et al. (2005) found similar relationships for M. furnieri in this region, it has not been possible to determine the reason for these results (MONSEFRAD et al., 2012; DSIKOWITZKY et al., 2013). More studies of the biomagnification and bioaccumulation processes of metals and metalloids are necessary, considering the importance of both species for the ecosystem and the fisheries.

Aquatic organisms can be used as bioindicators because vital functions or chemical composition can change in the environment on spatial or temporal scales. This provides a measure of exposure and susceptibility to different pollutants. Good bioindicators are usually non-migratory species which are more likely to reflect the characteristics of the aquatic environment with higher accuracy (RODRÍGUEZ et al., 2009). In the present study, it was found that $M$. furnieri accumulates contaminants in its tissue. Given that it is a highly mobile species, the source of the contaminants cannot be determined. This species, however, has been cited as a bioindicator in other regions (MARCOVECCHIO, 2004). The fish caught along the Montevideo coastal zone showed no differences in the levels of metals and metalloid. As such, whether this species can be used as 
Table 4. Total length and mean values $( \pm \mathrm{SD})$ of metals $(\mathrm{Cu}, \mathrm{Zn}, \mathrm{Hg})$ reported in regionals studies.

\begin{tabular}{|c|c|c|c|c|c|c|}
\hline \multicolumn{7}{|l|}{ Micropogonias furnieri } \\
\hline Location (tissue, season) & Total Length $(\mathrm{cm})$ & $\mathrm{N}$ & $\mathrm{Cu}$ & $\mathrm{Zn}$ & $\mathrm{Hg}$ & Reference \\
\hline Samborombón Bay, Argentina (muscle) & & & & $20.5 \pm 4.86$ & $0.11 \pm 0.04$ & Marcovecchio, 2004 \\
\hline Samborombón Bay, Argentina (liver) & & & & $44.3 \pm 6.20$ & $0.13 \pm 0.04$ & Marcovecchio, 2004 \\
\hline Uruguayan coastal zone, Uruguay (muscle) a & & & $<0.18$ & 3.06 & 0.11 & Viana et al., 2005 \\
\hline Uruguayan coastal zone, Uruguay (liver) a & & & 11.75 & 37.25 & 0.19 & Viana et al., 2005 \\
\hline Guanabara Bay, Brazil (muscle) & $46.2(35.0-57.7)$ & 22 & $0.6 \pm 0.3$ & $3.2 \pm 0.5$ & $0.3 \pm 0.2$ & Kehrig et al., 2007 \\
\hline Cananéia-Iguape, Brazil (muscle) & $46.1 \pm 2.5(41.4-50.7)$ & 11 & & & $0.236 \pm 0.111$ & Curcho et al., 2009 \\
\hline Patos Lagoon, Brazil (muscle) & $(48-50)$ (fork) & 2 & & & 0.0534 & Kütter et al., 2009 \\
\hline Guanabara Bay, Brazil (muscle, winter) & +40.0 & 7 & & & $0.252 \pm 0.214$ & Bisi et al., 2012 \\
\hline Guanabara Bay, Brazil (muscle, summer) & +40.0 & 7 & & & $0.111 \pm 0.046$ & Bisi et al., 2012 \\
\hline Sepetiba Bay, Brazil (muscle, winter) & +40.0 & 7 & & & $0.1076 \pm 0.134$ & Bisi et al., 2012 \\
\hline Sepetiba Bay, Brazil (muscle, summer) & +40.0 & 5 & & & $0.135 \pm 0.099$ & Bisi et al., 2012 \\
\hline Ilha Grande Bay, Brazil (muscle, winter) & +40.0 & 10 & & & $0.264 \pm 0.096$ & Bisi et al., 2012 \\
\hline Ilha Grande Bay, Brazil (muscle, summer) & +40.0 & 7 & & & $0.2261 \pm 0.126$ & Bisi et al., 2012 \\
\hline Montevideo, Uruguay (muscle, winter 10) & $46.0 \pm 5.8(38.0-62.0)$ & 18 & $0.40 \pm 0.18$ & $3.38 \pm 0.48$ & $0.10 \pm 0.13$ & This study \\
\hline Montevideo, Uruguay (muscle, spring 10) & $42.3 \pm 6.4(34.0-52.5)$ & 18 & $0.47 \pm 0.12$ & $3.41 \pm 0.66$ & $0.04 \pm 0.01$ & This study \\
\hline Montevideo, Uruguay (muscle, spring 11) & $51.2 \pm 10.3(28.5-63.0)$ & 25 & $0.32 \pm 0.16$ & $3.96 \pm 0.50$ & $0.11 \pm 0.10$ & This study \\
\hline Montevideo, Uruguay (liver, winter 10) & $46.0 \pm 5.8(38.0-62.0)$ & 4 & $16.97 \pm 3.56$ & $38.56 \pm 7.57$ & & This study \\
\hline Montevideo, Uruguay (liver, spring 10) & $42.3 \pm 6.4(34.0-52.5)$ & 2 & $23.40 \pm 1.33$ & $33.75 \pm 4.54$ & & This study \\
\hline Montevideo, Uruguay (liver, spring 11) & $51.2 \pm 10.3(28.5-63.0)$ & 16 & $19.95 \pm 9.70$ & $44.48 \pm 7.93$ & & This study \\
\hline \multicolumn{7}{|l|}{ Mugil spp. } \\
\hline Samborombón Bay, Argentina (muscle)* & & & & $48.8 \pm 3.99$ & $0.40 \pm 0.06$ & Marcovecchio, 2004 \\
\hline Samborombón Bay, Argentina (liver)* & & & & $52.0 \pm 4.14$ & $0.53 \pm 0.11$ & Marcovecchio, 2004 \\
\hline Uruguayan coastal zone, Uruguay (muscle)*** a & & & $<0.25$ & 4.83 & 0.06 & Viana et al., 2005 \\
\hline Uruguayan coastal zone, Uruguay (liver)** a & & & 147.9 & 64.2 & 0.21 & Viana et al., 2005 \\
\hline Guanabara Bay, Brazil (muscle)* & $41.1(37.0-50.0)$ & 22 & $0.4 \pm 0.2$ & $3.8 \pm 1.3$ & $0.02 \pm 0.004$ & Kehrig et al., 2007 \\
\hline Cananéia-Iguape, Brazil (muscle)** & $54.4 \pm 5.1(43.2-60.0)$ & 14 & & & $0.0083 \pm 0.0056$ & Curcho et al., 2009 \\
\hline Patos Lagoon, Brazil (muscle)** & (31-50) (fork) & 4 & & & 0.0124 & Kütter et al., 2009 \\
\hline Guanabara Bay, Brazil (muscle, summer)* & & 5 & & & $0.0121 \pm 0.0036$ & Bisi et al., 2012 \\
\hline Ilha Grande Bay, Brazil (muscle)* b & $(52.0-62.0)$ & 15 & & & $0.00415 \pm 0.0036$ & Seixas et al., 2013 \\
\hline Guanabara Bay, Brazil (muscle)* b & $(36.0-50.0)$ & 19 & & & $0.0181 \pm 0.00415$ & Seixas et al., 2013 \\
\hline Montevideo, Uruguay (muscle, winter 10)** & $50.5 \pm 3.5(44.0-54.0)$ & 6 & $0.72 \pm 0.09$ & $4.47 \pm 0.87$ & $<0.04$ & This study \\
\hline Montevideo, Uruguay (muscle, spring 11)** & $43.4 \pm 11.45(30.0-58.0)$ & 8 & $0.55 \pm 0.41$ & $4.82 \pm 0.64$ & $<0.04$ & This study \\
\hline Montevideo, Uruguay (liver, winter 10)** & $50.5 \pm 3.5(44.0-54.0)$ & 3 & $458.03 \pm 114.66$ & $103.25 \pm 18.44$ & & This study \\
\hline Montevideo, Uruguay (liver, spring 11)** & $43.4 \pm 11.45(30.0-58.0)$ & 4 & $508.46 \pm 337.22$ & $87.55 \pm 37.47$ & & This study \\
\hline
\end{tabular}

Notes: Mean concentrations in $\mu \mathrm{g} \mathrm{g}{ }^{-1}$ W.W. N: total number of individuals analyzed. For As no data found in the above references except in the present study. * Mugil liza, ** Mugil platanus. a Concentrations expressed in dry weight were converted to W.W. using the factors estimated in this study (wet wt./dry wt.) of 0.18 and 0.25 for muscle and liver of M. furnieri, and of 0.23 and 0.30 for muscle and liver of M. platanus; $\mathrm{b}$ Concentrations expressed in dry weight were converted to W.W. using the factor of 0.25 used by SEIXAS et al., 2013.

a spatial bioindicator remains an open question. Future assessments of environmental quality for this region should consider fish species with territorial behavior. Despite these findings, the importance of $M$. furnieri as a temporal bioindicator should still be considered. The Hg concentrations in this present study showed a reduction compared to those found by VIANA et al. (2005). These results do, however, support $M$. furnieri as a bioindicator for temporal variation of $\mathrm{Hg}$ along the Montevideo coastal zone.

Because the concentrations of $\mathrm{Hg}$ in muscle were consistently lower than the safety values (CODEX-STAN 193-1995, 2010; MERCOSUR, 2011), it can be concluded that, for this metal, the consumption of $M$. furnieri in the Montevideo coastal zone is not hazardous for human health. 


\section{ACKNOWLEDGEMENTS}

The authors would like to thank SNI-ANII, CSICVUSP (UdelaR), Administración Nacional de Puertos (ANP) (Uruguay) and Project RLA 5/054-001 (ARCALOIEA), for the partial funding provided for the development of this study. They also wish to express their thanks to: Rosario Odino, Adriana Gabrielli, Lourdes Piuma and Ethel Reina for the analysis of $\mathrm{Cu}, \mathrm{Zn}$ metals and As metalloid (Laboratorios de Tecnogestión, Ministerio de Industria, Energía y Minería, Uruguay); $\mathrm{PhD}$ Beatriz Baliño, University of Bergen, for technical recomendations and proofreading. To the colleagues of the Department of Oceanography and Marine Ecology (Facultad de Ciencias) for their assistance in this project. We are also grateful for the suggestions of the reviewer which permitted us to improve this document.

\section{REFERENCES}

ABDOLAHPUR, M. F.; SAFAHIEH, A.; SAVARI, A.; DORAGHI, A. Heavy metal concentration in sediment, benthic, benthopelagic, and pelagic fish species from Musa Estuary (Persian Gulf). Environ. Monit. Assess.,v. 185 , n. 1, p. 215-222, 2013.

BISI, T. L.; LEPOINT, G.; AZEVEDO, A. F.; DORNELES, P. R.; FLACH, L.; DAS, K.; MALM, O.; LAILSON-BRITO, $\mathrm{J}$. Trophic relationships and mercury biomagnification in Brazilian tropical coastal food webs. Ecol. Indic., v. 18, p. 291-302, 2012

BRUGNOLI, E.; MUNIZ, P.; VENTURINI, N.; BURONE, L. Environmental perturbation and coastal benthic biodiversity in Uruguay. In: WILLIS, I. C. (Ed.). Progress in Environmental Research. New York: Nova Publishers, 2007. p. $75-126$.

BURGER, J.; GOCHFELD, M. Heavy metals in commercial fish in New Jersey. Environ. Res., v. 99, n. 3, p. 403-412, 2005.

CHENG, Z.; CHEN, K. C.; LI, K. B.; NIE, X. P.; WU, S. C.; WONG, C. K.; WONG, M. H. Arsenic contamination in the freshwater fish ponds of Pearl River Delta: bioaccumulation and health risk assessment. Environ. Sci. Pollut. Res., v. 20, n. 7, p. 4484-4495, 2013

CODEX STAN 193-1995. Codex General Standard for Contaminants and toxins in food and feed. 2010. 39 p. Available from: <http://www.codexalimentarius.net/download/ standards/17/CXS 193e.pdf $>$. Accessed 5 Jul 2014.

CURCHO, M. R. S. M.; FARIAS, L. A.; BAGGIO, S. R.; FONSECA, B. C.; NASCIMENTO, S. M.; BORTOLI, M. C.; BRAGA, E. S.; FÁVARO, D. I. T. Mercury and methylmercury content, fatty acids profile, and proximate composition of consumed fish in Cananéia, São Paulo, Brazil. Rev. Inst. Adolfo Lutz, v. 68, n. 3, p. 442-450, 2009.

DANULAT, E.; MUNIZ, P.; GARCÍA-ALONSO, J.; YANNICELLI, B. First assessment of the highly contaminated harbour of Montevideo, Uruguay. Mar. Pollut. Bull.,v. 44, n. 6, p. $551-576,2002$.
DEFEO, O.; HORTA, S.; CARRANZA, A.; LERCARI, D.; DE ALAVA, A.; GOMEZ, J.; MARTINEZ, G.; LOZOYA, J. P.; CELENTANO, E. Hacia un manejo ecosistémico de las pesquerías. Áreas Marinas Protegidas en Uruguay. Montevideo: Facultad de Ciencias-DINARA, 2009, 122 p.

DSIKOWITZKY, L.; MENGESHA, M.; DADEBO, E.; CARVALHO, C. E. V.; SINDERN, S. Assessment of heavy metals in water samples and tissues of edible fish species from Awassa and Koka Rift Valley Lakes, Ethiopia. Environ. Monit. Assess., v. 185, n. 4, p. 3117-3131, 2013.

FISCHER, L. G.; PEREIRA, L. E. D.; VIEIRA, J. P. Peixes estuarinos e costeiros. 2a. ed. Rio Grande, 2011. 131 p.

FRANCO, A. J.; LEÓN, I. M. Bioacumulación de metales traza en Mugil incilis (Hancock, 1830); una herramienta útil para el biomonitoreo de la contaminación metálica en el litoral costero del departamento del Atlántico-Colombia. In: UNESCO Office Montevideo and Regional Bureau for Science in Latin America and the Caribbean. (Ed.). Costas: Revista Iberoamericana de Manejo Costero Integrado. Montevideo: UNESCO Office Montevideo, 2012. p. 98-106.

HATCH, W. R.; OTT, W. L. Determination of submicrogram quantities of mercury by atomic absorption spectrophotometry. Anal. Chem., v. 40, n. 14, p. 2085-2087, 1968.

JAUREGUIZAR，A. J.; MILITELLI， M. I.; GUERRERO, R. Distribution of Micropogonias furnieri at different maturity stages along an estuarine gradient and in relation to environmental factors. J. Mar. Biol. Assoc. UK, v. 88, n. 1, p. 175-181, 2008.

KEHRIG, H. A; COSTA, M.; MALM, O. Estudo da contaminação por metais pesados em peixes e mexilhão da Baia de Guanabara - Rio de Janeiro. Trop. Oceanogr. Onl., v. 35, n. 1, p. 32-50, 2007.

KÜTTER, V. T.; MIRLEAN, N.; BAISCH, P. R. M.; KÜTTER, M. T.; SILVA-FILHO, E. V. Mercury in freshwater, estuarine, and marine fishes from Southern Brazil and its ecological implication. Environ. Monit. Assess., v. 159, p. 35-42, 2009.

LOMBARDI, P. E.; PERI, S. I.; VERRENGIA GUERRERO, N. R. Trace metal levels in Prochilodus lineatus collected from the La Plata River, Argentina. Environ. Monit. Assess., v. 160, p. 47-59, 2010.

LUOMA, S. N.; RAINBOW, P. S. Metal Contamination in Aquatic Environments: science and lateral management. Cambridge: Cambridge University Press, 2011. p. 588.

MACEDA-VEIGA, A.; MONROY, M.; DE SOSTOA, A. Metal bioaccumulation in the Mediterranean barbel (Barbus meridionalis) in a mediterranean river receiving effluents from urban and industrial wastewater treatment plants. Ecotoxicol. Environ. Saf., v. 76, p. 93-101, 2012.

MARCOVECCHIO, J. E. The use of Micropogonias furnieri and Mugil liza as bioindicators of heavy metals pollution in La Plata river estuary, Argentina. Sci. Total. Environ.,v. 323, p. 219- 226, 2004

MENDEZ, E.; GIUDICE, H.; PEREIRA, A.; INOCENTE, G.; MEDINA, D. Total mercury content-fish weight relationship in swordfish (Xiphias gladius) caught in the South Atlantic Ocean. J. Food. Compost. Anal., v. 14, p. 453-460, 2001.

MENDOZA-CARRANZA, M.; VIEIRA, J. Whitemouth croaker Micropogonias furnieri (Desmarest, 1823) feeding strategies across four southern Brazilian estuaries. Aquat. Ecol., v. 42, n. 1, p. 83-93, 2008 
MERCOSUR/GMC/RES. No 12/11. Reglamento técnico MERCOSUR sobre límites máximos de contaminantes inorgánicos en alimentos. (Derogación de las RES.GMC N ${ }^{\circ}$ 102/94 y No 35/96). Asunción, 2011. 18 p.

MONSEFRAD, F.; IMANPOUR NAMIN, J.; HEIDARY, S. Concentration of heavy and toxic metals $\mathrm{Cu}, \mathrm{Zn}, \mathrm{Cd}, \mathrm{Pb}$ and $\mathrm{Hg}$ in liver and muscles of Rutilus frisii kutum during spawning season with respect to growth parameters. Iran. J. Fish. Sci., v. 11, n. 4, p. 825-839, 2012.

MUNIZ, P.; DANULAT, E.; YANNICELLI, B.; GARCÍAALONSO, J.; MEDINA, G.; BÍCEGO, M. C. Assessment of contamination by heavy metals and petroleum hydrocarbons in sediments of Montevideo Harbour (Uruguay). Environ. Int., v. 29, n. 8, p. 1019-1028, 2004.

MUNIZ, P.; VENTURINI, N.; HUTTON, M.; KANDRATAVICIUS, N.; PITA, A.; BRUGNOLI, E.; BURONE, L.; GARCÍA-RODRÍGUEZ, F. Ecosystem health of Montevideo coastal zone: A multi approach using some different benthic indicators to improve a ten-year-ago assessment. J. Sea Res., v. 65, n. 1, p. 38-50, 2011.

NIÓN, H. Fishes of the Río de La Plata and some aspects of their ecology. In: WELLS, P. G.; DABORN, G. R. (Eds). The Río de La Plata - An environamental overview. An Ecoplata Project Background Report. Halifax: Dalhousie University, 1997. p. 163-185.

QADIR, A.; MALIK, R. N. Heavy metals in eight edible fish species from two polluted tributaries (Aik and Palkhu) of the River Chenab, Pakistan. Biol. Trace. Elem. Res., v. 143, n. 3, p. 1524-1540, 2011

REJOMON, G.; NAIR, M.; JOSEPH, T. Trace metal dynamics in fishes from the southwest coast of India. Environ. Monit. Assess., v. 167, p. 243-255, 2010.
RODRÍGUEZ FORERO, A.; GONZÁLEZ MANTILLA, J. F.; SUÁREZ MARTÍNEZ, R. Accumulation of lead, chromium, and cadmium in muscle of capitán (Eremophilus mutisii), a catfish from the Bogota River basin. Arch. Environ. Contam. Toxicol., v. 57, n. 2, p. 359-365, 2009.

SEIXAS, T. G.; MOREIRA, I.; MALM, O.; KEHRIG, H. A. Ecological and biological determinants of methylmercury accumulation in tropical coastal fish. Environ. Sci. Pollut. Res. Int., v. 20, n. 2, p. 1142-1150, 2013.

SERICANO, J.; BESADA, V. Recomendaciones para la toma y preparación de muestras de bivalvos y peces. Manual preparado para el "Programa Regional para el Biomonitoreo de Contaminantes en Moluscos y peces" RLA/5/054 (ARCAL), 2009.

TAGLIAMONTE, F.; BESSONART, M.; FOGLIA, M.; SALHI, M. Determinación de mercurio y cadmio en Otaria flavescens (Shaw, 1800) y Arctocephalus australis (Zimmermann, 1783) en Uruguay. XIII Reunión de Trabajo de Especialistas en Mamíferos Acuáticos de América del Sur y $7^{\circ}$ Congreso SOLAMAC, Montevideo, 2008. p. 93.

VIANA, F.; HUERTAS, R.; DANULAT, E. Heavy metal levels in fish from coastal waters of Uruguay. Arch. Environ. Contam. Toxicol., v. 48, p. 530-537, 2005.

WANG, Y.; CHEN, P.; CUI, R.; SI, W.; ZHANG, Y.; JI, W. Heavy metal concentration in water, sediment, and tissues of two species (Triplohysa pappenheimi, Gobioh wanghensis) from the Lanzhou section of the Yellow River, China. Environ. Monit. Assess., v. 165, p. 97-102, 2010.

ZAR, J. H. Biostatistical Analysis. 3rd.ed. New Jersey: Prentice Hall, 1996. 662 p. 
